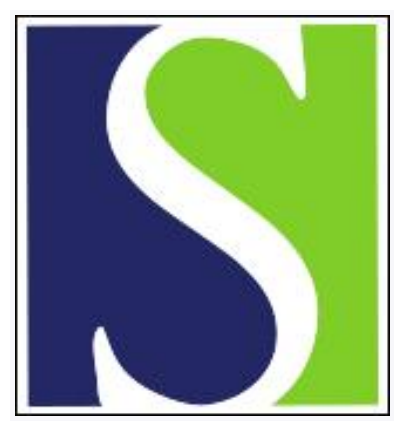

Scand J Work Environ Health 1999;25(3):238-245

https://doi.org/10.5271/sjweh.430

Issue date: Jun 1999

Exposure-response relationship between gastrointestinal problems among waste collectors and bioaerosol exposure by Ivens UI, Breum NO, Ebbehøj N, Nielsen BH, Poulsen OM, Würtz H

Key terms: job-exposure matrix; occupational epidemiology; occupational exposure; waste

This article in PubMed: www.ncbi.nlm.nih.gov/pubmed/10450775

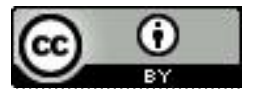




\title{
Exposure-response relationship between gastrointestinal problems among waste collectors and bioaerosol exposure
}

\author{
by Ulla I Ivens, PhD, ${ }^{1}$ Niels O Breum, PhD, ${ }^{2}$ Niels Ebbehøj, MD, ${ }^{4}$ Birgitte H Nielsen, PhD, ${ }^{3}$ Otto $M$ \\ Poulsen, DrVetMed, ${ }^{3}$ Helle Würtz, $M S c^{3}$
}

\begin{abstract}
Ivens UI, Breum NO, Ebbehøj N, Nielsen BH, Poulsen OM, Würtz H. Exposure-response relationship between gastrointestinal problems among waste collectors and bioaerosol exposure. Scand $J$ Work Environ Health $1999 ; 25(3): 238-245$.
\end{abstract}

\begin{abstract}
Objectives A high frequency of gastrointestinal problems has previously been reported for waste collectors. The present study relates the gastrointestinal problems to measurements of the bioaerosols that waste collectors are exposed to during work.

Methods A job-exposure matrix was constructed from a combination of questionnaire data and field measurements. The questionnaire data were collected from 1747 male waste collectors and a comparison group of 1111 male municipal workers. Moreover a total of 189 full-shift personal samples was collected. The samples were used for characterizing the bioaerosol exposure described by viable fungi, total count of fungal spores, microorganisms, and endotoxins.

Results In a multivariate analysis, high exposure to endotoxins was associated with nausea [prevalence proportion ratio (PPR) 1.60], and the risk of reporting nausea decreased with decreasing exposure so that workers with low exposure had the fewest reports (PPR 1.39) in the comparison with the unexposed group. High exposure to endotoxins was also associated with reports of diarrhea (PPR 5.60), and the risk of reporting diarrhea decreased with decreasing exposure so that the workers with low exposure had the fewest reports (PPR 3.02). The same pattern existed for exposure to fungi, for which high exposure resulted in the most reports ( $P P R=4.59$ ), and for diarrhea, for which low exposure resulted in the fewest reports ( $P P R=3.15$ ).

Conclusions An exposure-response relationship was found between nausea and endotoxin exposure and between diarrhea and exposure to both endotoxins and viable fungi.
\end{abstract}

Key terms job-exposure matrix, occupational epidemiology, occupational exposure, waste.

The governments of several western countries have decided that dumping waste in landfills is to be replaced by recycling for up to $50 \%$ of household waste (1). The recycled waste can be used for energy production by incineration or biogas production, for composting, or for reuse. The sorting of mixed household waste is known to be hazardous (2), and the recycling can involve source separation at the household site into, for example, a combustible fraction, an organic fraction, and a fraction of paper and glass (table 1). Collection of several waste fractions can prolong the collection frequency from once a week to every second week or more and, therefore, create favorable conditions for the growth of microorganisms (eg, fungi and endotoxins) (3-4). Fungi are known to cause, for example, respiratory symptoms (5-7). Endotoxins have previously been suggested as a cause of gastrointestinal symptoms (8-11).

A high frequency of gastrointestinal problems among waste collectors has been reported in minor case studies (12), especially in the warm season and when the organic fraction of household waste is collected (13). A recent large nationwide questionnaire-based study among almost all Danish waste collectors confirmed this earlier finding, in addition to showing that the symptoms are work-related (14). To our knowledge, no other studies exist on the relationship between gastrointestinal problems and work as a waste collector (1). In addition, no study seems available on the exposure-response relation-

1 Department of Occupational Medicine, National Institute of Occupational Health, Copenhagen, Denmark.

2 Department of Occupational Hygiene, National Institute of Occupational Health, Copenhagen, Denmark.

3 Department of Toxicology and Biology, National Institute of Occupational Health, Copenhagen, Denmark.

4 Department of Occupational and Environmental Medicine, Copenhagen, Denmark,

Reprint requests to: Dr NO Breum, National Institute of Occupational Health, Lers $\varnothing$ Parkallé 105, 2100 Copenhagen $\varnothing$, Denmark. [E-mail: nob@ami.dk] 
ship between exposure to fungi or endotoxins and gastrointestinal problems. A preliminary description of the specific relationship between diarrhea and fungi exposure has previously been presented (15).

A precise, reliable, and effective means of evaluating the relationship between work processes, and exposure and health outcome is the job-exposure matrix (1617). A job-exposure matrix, based on the integration of questionnaire data and field measurements, was used in this study to establish exposure-response relationships between bioaerosol exposure and gastrointestinal problems.

\section{Subjects and methods}

The study population consisted of 2303 male waste collectors with a mean number of 34 (range 7-74) workhours per week. These men comprised all the employees in the waste collection companies in Denmark that agreed to participate in the study ( $94 \%$ of all such companies in Denmark) $(14,18)$. They were sent a questionnaire focusing on the present and past work environment, work-related exposures, the psychosocial work environment, background information, and health status. The response rate was $76 \%$. The questionnaire was also sent to a comparison group of 1430 male municipal workers in mainly outdoor jobs (road men, other mainly outdoor job functions, and unskilled gardeners), and $82 \%$ replied. The comparison group was assumed to have only a very low level of bioaerosol exposure. Only unskilled gardeners were used in this study $(19-20)$.

\section{Questions on exposure}

Questions about exposure followed the idea of the MUSIC study (21), and the psychosocial questions were from the Whitehall studies (22), which are related to the demand-control-support model (23-24).

It was expected that the individual employees would not be aware of the agents they were exposed to during different job tasks (25); therefore the questionnaire was constructed to identify job tasks instead of exposure. Thus present work conditions dealt with the type of waste collected, the type of bin used for waste storage, the type of collection truck, job function, and shifts between job functions (26). The types of waste are presented in table 1. The types of bins are shown in table 2 . The collection trucks included compactor trucks with high or low scoops and platform trucks. Job functions were divided into driver, front runner (runs in front of the truck and tugs the garbage containers out to the road), loader (takes the container at the roadside and tugs it into the truck) and mixed function (shifts between the different job functions during the day, from day to day or from week to week). For each question a specification of time spent during a day was requested. Afterwards the time was grouped into " $3 / 4$ of the day or more", or " $1 / 2$ of the day or less".

Table 1. Waste fractions collected by waste collectors.

\begin{tabular}{|c|c|c|}
\hline Waste fraction & Waste type & Specification \\
\hline \multirow{3}{*}{$\begin{array}{l}\text { Organic, residual, } \\
\text { and mixed household } \\
\text { waste }\end{array}$} & Organic waste & $\begin{array}{l}\text { Wet, green part of } \\
\text { household waste }\end{array}$ \\
\hline & Residual waste & $\begin{array}{l}\text { Dry, remaining } \\
\text { fraction when the } \\
\text { organic part has } \\
\text { been separated }\end{array}$ \\
\hline & Mixed household waste & Unseparated fraction \\
\hline Paper & Paper \& cardboard & $\begin{array}{l}\text { Separated by the } \\
\text { household }\end{array}$ \\
\hline Glass & $\begin{array}{l}\text { Bottles \& other glass } \\
\text { objects }\end{array}$ & $\begin{array}{l}\text { Separated by the } \\
\text { household }\end{array}$ \\
\hline Garden & Garden waste & $\begin{array}{l}\text { Separated by the } \\
\text { household }\end{array}$ \\
\hline
\end{tabular}

Table 2. Description of the different types of bags and containers used by waste collectors.

\begin{tabular}{|c|c|c|}
\hline Container group & Specification & Use \\
\hline Bags & Bags made of paper or plastic & $\begin{array}{l}\text { Paper bags mostly for unseparated household waste; } \\
\text { plastic bags mostly for garden waste - mainly rural } \\
\text { areas }\end{array}$ \\
\hline Containers without wheels (bins) & Bins made of plastic, volume $110-150$ I & $\begin{array}{l}\text { Used for organic waste, mixed household waste, the } \\
\text { residual fraction, garden waste - mainly used in } \\
\text { one-family houses or at locations where waste is placed } \\
\text { in or behind a narrow basement }\end{array}$ \\
\hline \multicolumn{3}{|l|}{ Containers with wheels } \\
\hline Divided containers with two wheels & Bins made of plastic, volume $190-3301$ & $\begin{array}{l}\text { Used for organic waste, mixed household waste, the } \\
\text { residual fraction, garden waste - mainly used in urban } \\
\text { areas (one-family houses and apartment buildings) }\end{array}$ \\
\hline Undivided containers with two wheels & & $\begin{array}{l}\text { Used for organic waste, mixed household waste, the } \\
\text { residual fraction, garden waste in areas where the waste } \\
\text { is to be separated - mainly used in urban areas } \\
\text { (one-family houses and apartment buildings) }\end{array}$ \\
\hline Containers with four wheels & Containers made of plastic, volume $300-600$ I & $\begin{array}{l}\text { Used for mixed household waste, the residual fraction, } \\
\text { paper, glass - mainly used in urban areas (apartment } \\
\text { buildings) }\end{array}$ \\
\hline
\end{tabular}


Eighty-three persons were excluded as they had answered "almost all day" to all the questions about daily number of workhours with various waste fractions or about the daily number of workhours in each job function, since such responses were considered invalid. The comparison group was regarded as unexposed to waste collection materials.

\section{Questions on health status}

Answers to questions about nausea and diarrhea were dichotomized, and the outcome was defined as symptoms some times per month or more often (27).

\section{Job-exposure matrix}

More-reliable exposure measurements were obtained by using the work processes, described by type of truck, bin, waste type, and job function in order of priority in place of single exposure parameters. An example of a work process was the use of a compactor truck with a low scoop, container with ( 2 or 4 ) wheels, biodegradable waste, mixed household waste or the residual fraction, and job function driver. Altogether 950 waste collectors were allocated into a particular work process. Each work process was defined on the basis of the questionnaire, and it was used in combination with data on the measured levels of bioaerosol exposure to form the job-exposure matrix.

Field measurements (189 full-shift samples) had been conducted among a sample of waste collectors to characterize the bioaerosol exposure, described by viable fungi, microorganisms (total microscopic counts of fungi and bacteria) and endotoxins (28). These exposure parameters are known or were hypothesized as causes of gastrointestinal or respiratory problems.

The following 3 approaches were used for the description of the bioaerosol exposure for each work process: (i) field measurements conducted among waste collectors working with exactly one of the work processes

Table 3. Bioaerosol exposure of the waste collectors. ( $\mathrm{N} 1=$ number of participants from the questionnaire study, $\mathrm{N} 2=$ number of participants in the field measurements, $\mathrm{cfu}=$ colony-forming units, $\mathrm{CT}=$ compactor truck, $\mathrm{ORH}=$ organic, residual, and mixed household waste fraction, mixed (job) function = shift in job function during the day or from day to day or week to week)

\begin{tabular}{|c|c|c|c|c|c|c|c|c|c|c|}
\hline \multirow[t]{2}{*}{ Type of truck } & \multirow[t]{2}{*}{ Type of bin } & \multirow[t]{2}{*}{ Type of waste } & \multirow[t]{2}{*}{ Job function } & \multirow[t]{2}{*}{ N1 } & \multirow[t]{2}{*}{ N2 } & \multirow[t]{2}{*}{$V^{a}$} & \multicolumn{4}{|c|}{ Level of exposure } \\
\hline & & & & & & & $\begin{array}{c}\text { Fungi } \\
\left(10^{3} \mathrm{cfu} / \mathrm{m}^{3}\right)\end{array}$ & $\begin{array}{c}\text { Total } \\
\text { fungi } \\
\left(10^{3} \mathrm{cells} / \mathrm{m}^{3}\right)\end{array}$ & $\begin{array}{c}\text { Total } \\
\text { microor- } \\
\text { ganism } \\
\left(10^{3} \text { cells } / \mathrm{m}^{3}\right)\end{array}$ & $\begin{array}{c}\text { Endotoxins } \\
\left(\mathrm{EU} / \mathrm{m}^{3}\right)\end{array}$ \\
\hline \multirow[t]{3}{*}{$\begin{array}{l}\mathrm{CT} \text {, low } \\
\text { loaded }\end{array}$} & Containers & $\mathrm{ORH}$ & $\begin{array}{l}\text { Driver } \\
\text { Front runner } \\
\text { Loader } \\
\text { Mixed function }\end{array}$ & $\begin{array}{r}7 \\
3 \\
5 \\
105\end{array}$ & $\begin{array}{r}2 \\
3 \\
8 \\
47\end{array}$ & $\begin{array}{l}20 \\
45 \\
35 \\
30\end{array}$ & $\begin{array}{r}37 \\
25 \\
180 \\
87\end{array}$ & $\begin{array}{r}59 \\
71 \\
340 \\
240\end{array}$ & $\begin{array}{r}59 \\
120 \\
490 \\
330\end{array}$ & $\begin{array}{l}1.8 \\
1.8 \\
5.8 \\
9.1\end{array}$ \\
\hline & Bins $^{b}$ & $\mathrm{ORH}$ & $\begin{array}{l}\text { Driver } \\
\text { Front runner } \\
\text { Loader } \\
\text { Mixed function }\end{array}$ & $\begin{array}{r}- \\
\overline{1} \\
26\end{array}$ & $\begin{array}{r}- \\
1 \\
- \\
14\end{array}$ & $\begin{array}{l}20 \\
45 \\
35 \\
30\end{array}$ & $\begin{array}{r}38 \\
26 \\
190 \\
91\end{array}$ & $\begin{array}{r}56 \\
67 \\
320 \\
230\end{array}$ & $\begin{array}{r}85 \\
170 \\
710 \\
480\end{array}$ & $\begin{array}{l}1.8 \\
1.8 \\
5.9 \\
9.2\end{array}$ \\
\hline & Sacks & $\mathrm{ORH}$ & $\begin{array}{l}\text { Driver } \\
\text { Front runner } \\
\text { Loader } \\
\text { Mixed function }\end{array}$ & $\begin{array}{r}25 \\
32 \\
32 \\
255\end{array}$ & $\begin{array}{r}- \\
- \\
2 \\
18\end{array}$ & $\begin{array}{l}20 \\
45 \\
35 \\
30\end{array}$ & $\begin{array}{l}19 \\
13 \\
92 \\
45\end{array}$ & $\begin{array}{r}31 \\
37 \\
180 \\
130\end{array}$ & $\begin{array}{r}35 \\
69 \\
290 \\
200\end{array}$ & $\begin{array}{r}0.83 \\
0.83 \\
2.8 \\
4.3\end{array}$ \\
\hline \multirow[t]{3}{*}{$\begin{array}{l}\text { CT, high } \\
\text { loaded }\end{array}$} & Containers & $\mathrm{ORH}$ & $\begin{array}{l}\text { Driver } \\
\text { Front runner } \\
\text { Loader } \\
\text { Mixed function }\end{array}$ & $\begin{array}{r}4 \\
2 \\
5 \\
87\end{array}$ & $\begin{array}{r}1 \\
1 \\
- \\
21\end{array}$ & $\begin{array}{l}20 \\
45 \\
35 \\
30\end{array}$ & $\begin{array}{r}9 \\
25 \\
45 \\
22\end{array}$ & $\begin{array}{r}18 \\
71 \\
110 \\
75\end{array}$ & $\begin{array}{r}42 \\
120 \\
350 \\
240\end{array}$ & $\begin{array}{l}1.3 \\
1.8 \\
4.3 \\
6.8\end{array}$ \\
\hline & Bins $^{b}$ & $\mathrm{ORH}$ & $\begin{array}{l}\text { Driver } \\
\text { Front runner } \\
\text { Loader } \\
\text { Mixed function }\end{array}$ & $\begin{array}{r}- \\
- \\
13\end{array}$ & $\begin{array}{l}- \\
- \\
-\end{array}$ & $\begin{array}{l}20 \\
45 \\
35 \\
30\end{array}$ & $\begin{array}{r}10 \\
7 \\
47 \\
23\end{array}$ & $\begin{array}{l}17 \\
21 \\
99 \\
71\end{array}$ & $\begin{array}{r}61 \\
120 \\
510 \\
340\end{array}$ & $\begin{array}{l}1.3 \\
1.3 \\
4.4 \\
6.9\end{array}$ \\
\hline & Sacks & $\mathrm{ORH}$ & $\begin{array}{l}\text { Driver } \\
\text { Front runner } \\
\text { Loader } \\
\text { Mixed function }\end{array}$ & $\begin{array}{r}4 \\
10 \\
10 \\
70\end{array}$ & $\begin{array}{l}- \\
- \\
- \\
-\end{array}$ & $\begin{array}{l}20 \\
45 \\
35 \\
30\end{array}$ & $\begin{array}{r}5 \\
3 \\
23 \\
11\end{array}$ & $\begin{array}{l}10 \\
12 \\
55 \\
39\end{array}$ & $\begin{array}{r}25 \\
49 \\
210 \\
140\end{array}$ & $\begin{array}{r}0.36 \\
0.36 \\
1.2 \\
1.9\end{array}$ \\
\hline \multirow[t]{2}{*}{$\begin{array}{l}\text { Platform } \\
\text { truck }\end{array}$} & Sacks & $\mathrm{ORH}$ & $\begin{array}{l}\text { Driver } \\
\text { Front runner } \\
\text { Loader } \\
\text { Mixed function }\end{array}$ & $\begin{array}{r}9 \\
7 \\
12 \\
69\end{array}$ & $\begin{array}{r}- \\
- \\
6 \\
13\end{array}$ & $\begin{array}{l}20 \\
45 \\
35 \\
30\end{array}$ & $\begin{array}{l}15 \\
10 \\
29 \\
36\end{array}$ & $\begin{array}{r}56 \\
67 \\
490 \\
230\end{array}$ & $\begin{array}{r}74 \\
140 \\
830 \\
420\end{array}$ & $\begin{array}{r}1.1 \\
1.1 \\
13 \\
5.7\end{array}$ \\
\hline & $\begin{array}{l}\text { Sacks } \\
\text { Bins } \\
\text { Containers }\end{array}$ & $\begin{array}{l}\text { Paper } \\
\text { Paper } \\
\text { Paper } \\
\text { Garden } \\
\text { Paper \& glass }\end{array}$ & $\begin{array}{l}- \\
- \\
- \\
- \\
-\end{array}$ & $\begin{array}{r}25 \\
7 \\
16 \\
13 \\
57\end{array}$ & $\begin{array}{r}- \\
10 \\
12 \\
12\end{array}$ & $\begin{array}{l}30 \\
30 \\
30 \\
30 \\
30\end{array}$ & $\begin{array}{r}4 \\
4 \\
4 \\
130 \\
15\end{array}$ & $\begin{array}{r}39 \\
39 \\
39 \\
410 \\
180\end{array}$ & $\begin{array}{l}150 \\
150 \\
150 \\
640 \\
240\end{array}$ & $\begin{array}{l}7.4 \\
7.4 \\
7.4 \\
2.9 \\
3.2\end{array}$ \\
\hline
\end{tabular}

a Lung ventilation rate, $\mathrm{l} / \mathrm{min}$.

b Bins without wheels indicates that there was no job description for the particular work process. 
(table 3) with at least 2 measurements per process (the median was used as the resulting exposure level); (ii) field measurements conducted among waste collectors working with exactly one of the work processes (table 3 ) but fewer than 2 measurements being collected per process (the exposure level was estimated as described under iii; (iii) no field measurements. For the third approach the exposure level was estimated by use of conversion factors from measurements conducted for single exposure parameters instead of for work processes. As an example, no measurements were conducted for the work process "front-runner", emptying bags with organic, residual or mixed household waste into a compactor truck with a low scoop. Instead measurements were conducted on the work process "mixed function", emptying bags with organic, residual, or mixed household waste into a compactor truck with a low scoop. The difference between these work processes was the job function. From the field measurements it was known that the level of fungi exposure of the front runners was 1.4 times the level of those with a "mixed function". Similarly, the total count of fungal spores, the total count of microorganisms, and the endotoxin concentration for front runners were $1.5,2.0$, and 0.6 times, respectively, those of the workers with a "mixed" function (28). Using these conversion factors made it possible to estimate the level of exposure among the people working with the aforementioned work process.

A weekly "inhaled" bioaerosol exposure was estimated for each work process by multiplying the level of exposure by the lung ventilation rate associated with the work process and the self-reported number of workhours per week (table 4). Afterwards exposure was grouped into 3 categoies to ensure high contrast between the groups. The limits for the weekly exposure are shown in table 5 . The comparison group was regarded as having no exposure.

\section{Statistical methods}

To determine whether there was an association between bioaerosol exposure and the occurrence of nausea and diarrhea, prevalence proportion ratios (PPR) were fit with a general modeling procedure ("Proc Genmod" in SAS) with binomial error and a $\log$ link function (29). Average alcohol consumption per day (calculated as the total amount of beer, wine and spirits), the psychosocial exposure measures "demand" and "job support", and smoking status (present, former, never) were used as explanatory variables (14). For each ratio, a $95 \%$ confidence interval $(95 \% \mathrm{CI})$ and a P-value for level of significance (Wald test) are shown.

No goodness-of-fit test on this generalized linear model exists. Instead the goodness-of-fit was calculated for the logistic model (Hosmer-Lemeshow test), which, as a result, would have estimated the prevalence odds ratio instead of the prevalence proportion ratio. In addition a test for discrimination was conducted. The area under the receiver operating curve (AUR) was used for this purpose. As a general rule, AUR $=0.5-$ no discrimination, AUR $\geq 0.7$ - acceptable discrimination, AUR $\geq 0.8$ - excellent discrimination, AUR $\geq 0.9$ - outstanding discrimination. As there can be perfect discrimination in a model with a poor fit, this analysis of the area under the receiver operating curve acted as a supplement and not as a substitute for the Hosmer-Lemeshow test for fit.

Trend was tested with a chi-square test.

\section{Results}

\section{Nausea}

Table 6 shows that there was a clear exposure-response relationship between endotoxin exposure and nausea. High exposure had the largest number of reports of nausea (PPR 1.60, 95\% CI 0.88-2.90), medium exposure had the second highest number of reports (PPR 1.41, 95\% CI 0.96-2.06), and low exposure the smallest number of reports (PPR 1.39, 95\% CI 0.79-2.43). The test for trend was accepted $(\mathrm{P}=0.005)$. Exposure to fungi also resulted in reports of nausea, however, not in a linear exposure-response association. Exposure to total counts of fungal spores and microorganisms resulted in a reverse linear association that indicated that the lowest level of exposure was associated with the most reports of nausea.

Table 4. Mean weekly exposure to viable and total counts of fungi, to total counts of microorganisms and to endotoxins. (SE = standard error of the mean, cfu = colony-forming units)

\begin{tabular}{lccc}
\hline Parameter & Mean & SE & Range \\
\hline Viable fungi (cfu) & $2.8 \cdot 10^{6}$ & $7.9 \cdot 10^{4}$ & $1.2 \cdot 10^{5}-1.8 \cdot 10^{7}$ \\
$\begin{array}{l}\text { Total count of } \\
\text { fungal spores (cells) }\end{array}$ & $9.2 \cdot 10^{6}$ & $2.4 \cdot 10^{5}$ & $2.4 \cdot 10^{5}-4.6 \cdot 10^{7}$ \\
$\begin{array}{l}\text { Total count of } \\
\text { microorganisms (cells) }\end{array}$ & $1.7 \cdot 10^{7}$ & $3.7 \cdot 10^{5}$ & $6.0 \cdot 10^{5}-7.8 \cdot 10^{7}$ \\
Endotoxins (EU) & $2.9 \cdot 10^{2}$ & $0.06 \cdot 10^{2}$ & $0.09 \cdot 10^{2}-12 \cdot 10^{2}$ \\
\hline
\end{tabular}

Table 5. Limits of weekly exposure. (cfu = colony-forming units)

\begin{tabular}{|c|c|c|c|}
\hline \multirow[t]{2}{*}{ Type of exposure } & \multicolumn{3}{|c|}{ Degree of exposure } \\
\hline & Low & Medium & High \\
\hline Fungi (cfu) & $1 \cdot 10^{5}-1 \cdot 10^{8}$ & $1.10^{6}-1.10^{7}$ & $>1 \cdot 10^{7}$ \\
\hline $\begin{array}{l}\text { Total count of } \\
\text { fungal spores (cells) }\end{array}$ & $2 \cdot 10^{5}-2 \cdot 10^{6}$ & $2 \cdot 10^{6}-2 \cdot 10^{7}$ & $>2 \cdot 10^{7}$ \\
\hline $\begin{array}{l}\text { Total count of } \\
\text { microorganisms (cells) }\end{array}$ & $6 \cdot 10^{5}-6 \cdot 10^{6}$ & $6 \cdot 10^{6}-6 \cdot 10^{7}$ & $>6 \cdot 10^{7}$ \\
\hline Endotoxins (EU) & $0.1-1 \cdot 10^{2}$ & $1 \cdot 10^{2}-5 \cdot 10^{2}$ & $>5 \cdot 10^{2}$ \\
\hline
\end{tabular}




\section{Diarrhea}

A linear exposure-response relationship was found between exposure to fungi and reports of diarrhea (table 7). Exposure to a high concentration of fungi resulted in the most reports of diarrhea (PPR 5.60, 95\% CI 2.3913.08), medium exposure resulted in fewer reports (PPR $3.45,95 \%$ CI $2.24-5.31$ ), and those who were the least exposed had the fewest such reports (PPR 3.02, 95\% CI $1.86-4.92)$. The test for trend was accepted $(\mathrm{P}=0.001)$.

A similar exposure-response relationship was found for endotoxin exposure. High exposure to endotoxins resulted in the most reports of diarrhea (PPR 4.59, 95\% CI 2.74-7.71), medium exposure in fewer reports (PPR $3.25,95 \%$ CI $2.11-5.00$ ), and low exposure in the fewest reports (PPR 3.15, 95\% CI 1.84-5.41). The test for trend was accepted $(\mathrm{P}<0.001)$. Exposure to total counts of fungal spores and total counts of microorganisms also resulted in reports of diarrhea. However, there was no tendency towards a higher exposure resulting in more reports.

\section{Discussion}

In a questionnaire-based survey of waste collectors in combination with detailed exposure measurements, exposure-response relationships were found for nausea and exposure to endotoxins, and for diarrhea and exposure to both endotoxins and viable fungi. The method applied to detect the relationship was a trade-specific job-exposure matrix (16). The level of bioaerosol exposure was obtained from field measurements, and the jobs or work processes were constructed from the exposure questions in the questionnaire. To our knowledge, our study among waste collectors is the first to show an exposure-response relationship between exposure to fungi and the occurrence of gastrointestinal problems. A relation between endotoxin exposure and gastrointestinal problems has been suggested in other studies also (8). However, our study indicates a causal relationship. The relationships between endotoxin exposure and both nausea and diarrhea have been shown in a laboratory experiment. In the experiment, exposure to 40 micrograms of endotoxin $\left(4.8 \times 10^{5} \mathrm{EU}\right)$ resulted in reports of nausea and diarrhea ( $\mathrm{J}$ Thorn, personal communication).

No study has been carried out earlier in which a quantitative job-exposure matrix has been used to evaluate the association between bioaerosol exposure and gastrointestinal problems. The relationships established in our study are biologically plausible. Moreover, it has been suggested that when a job-exposure matrix is used to detect excess risk, the agent in question should be common [prevalence exceeding $10 \%$ (30)]. If this criterion has been used for the job-exposure matrix approach in our study, the method would have appeared to be acceptable. The

Table 6. Multivariate analyses of the exposure-response relationship between the level of weekly bioaerosol exposure and nausea for the waste collectors. $\left(\mathrm{PP}_{1}=\right.$ percentage with nausea according to the total group size, $\mathrm{PP}_{2}=$ percentage with nausea according to the total population, $\mathrm{PPR}=$ prevalence proportion ratio, $95 \% \mathrm{Cl}=95 \%$ confidence interval, $p_{\text {trend }}=$ test for trend, $\mathrm{p}_{\text {trend2 }}=$ test for trend without the comparison group, $\mathrm{p}_{\mathrm{HL}}=$ Hosmer-Lemeshow's goodness-of-fit test, Area $_{\mathrm{BOC}}=$ area under the ROC curve, cfu $=$ colony-forming units)

\begin{tabular}{|c|c|c|c|c|c|c|c|c|c|c|}
\hline Parameter & $\begin{array}{l}\text { Level of } \\
\text { exposure }\end{array}$ & $\begin{array}{l}\text { Number of } \\
\text { exposed } \\
\text { persons }\end{array}$ & $\mathrm{PP}_{1}$ & $\mathrm{PP}_{2}$ & PPR & $95 \% \mathrm{Cl}$ & $p_{\text {trend }}$ & $p_{\text {trend? }}$ & $\mathrm{p}_{\mathrm{HL}}$ & Area $_{\mathrm{ROC}}$ \\
\hline \multicolumn{11}{|l|}{ Fungi $(c f u)^{a}$} \\
\hline $\begin{array}{l}\text { High exposure group } \\
\text { Medium exposure group } \\
\text { Low exposure group } \\
\text { Comparison group }\end{array}$ & $\begin{array}{c}>1 \cdot 10^{7} \\
>1 \cdot 10^{6}-1 \cdot 10^{7} \\
1 \cdot 10^{5}-1 \cdot 10^{6} \\
<1 \cdot 10^{5}\end{array}$ & $\begin{array}{r}10 \\
711 \\
229 \\
387\end{array}$ & $\begin{array}{r}10 \\
34 \\
11 \\
5\end{array}$ & $\begin{array}{l}1 \\
64 \\
19 \\
16\end{array}$ & $\begin{array}{r}1.60 \\
2.01 \\
1.89 \\
1\end{array}$ & $\begin{array}{l}0.24-10.67 \\
1.27-3.19 \\
1.09-3.27\end{array}$ & 0.007 & 0.88 & 0.37 & 0.70 \\
\hline \multicolumn{11}{|c|}{ Total count of fungal spores (cells) ${ }^{a}$} \\
\hline $\begin{array}{l}\text { High exposure group } \\
\text { Medium exposure group } \\
\text { Low exposure group } \\
\text { Comparison group }\end{array}$ & $\begin{array}{c}>2 \cdot 10^{7} \\
>2 \cdot 10^{6}-2 \cdot 10^{7} \\
2 \cdot 10^{5}-2 \cdot 10^{6} \\
<2 \cdot 10^{5}\end{array}$ & $\begin{array}{r}68 \\
813 \\
69 \\
387\end{array}$ & $\begin{array}{r}6 \\
12 \\
16 \\
5\end{array}$ & $\begin{array}{r}3 \\
72 \\
8 \\
16\end{array}$ & $\begin{array}{r}1.03 \\
2.00 \\
2.63 \\
1\end{array}$ & $\begin{array}{l}0.37-2.87 \\
1.27-3.16 \\
1.34-5.15\end{array}$ & 0.05 & 0.09 & 0.20 & 0.70 \\
\hline \multicolumn{11}{|c|}{ Total count of microorganisms (cells) ${ }^{3}$} \\
\hline $\begin{array}{l}\text { High exposure group } \\
\text { Medium exposure group } \\
\text { Low exposure group } \\
\text { Comparison group }\end{array}$ & $\begin{array}{c}>6 \cdot 10^{7} \\
>6 \cdot 10^{6}-6 \cdot 10^{7} \\
6 \cdot 10^{5}-6 \cdot 10^{6} \\
<6 \cdot 10^{5}\end{array}$ & $\begin{array}{r}18 \\
847 \\
85 \\
387\end{array}$ & $\begin{array}{r}5 \\
12 \\
12 \\
5\end{array}$ & $\begin{array}{r}1 \\
75 \\
8 \\
16\end{array}$ & $\begin{array}{r}0.89 \\
1.99 \\
2.04 \\
1\end{array}$ & $\begin{array}{l}0.13-6.15 \\
1.27-3.14 \\
1.01-4.14\end{array}$ & 0.009 & 0.80 & 0.72 & 0.69 \\
\hline \multicolumn{11}{|l|}{ Endotoxins (EU) $)^{a}$} \\
\hline $\begin{array}{l}\text { High exposure group } \\
\text { Medium exposure group } \\
\text { Low exposure group } \\
\text { Comparison group }\end{array}$ & $\begin{array}{c}>5 \cdot 10^{2} \\
>1 \cdot 10^{2}-5 \cdot 10^{2} \\
0.001 \cdot 10^{2}-1 \cdot 10^{2} \\
<0.001 \cdot 10^{2}\end{array}$ & $\begin{array}{r}90 \\
730 \\
130 \\
387\end{array}$ & $\begin{array}{r}14 \\
11 \\
12 \\
5\end{array}$ & $\begin{array}{l}10 \\
62 \\
12 \\
16\end{array}$ & $\begin{array}{r}1.60 \\
1.41 \\
1.39 \\
1\end{array}$ & $\begin{array}{c}0.88-2.90 \\
0.96-2.06 \\
0.79-2.43 \\
-\end{array}$ & 0.005 & 0.65 & 0.28 & 0.69 \\
\hline
\end{tabular}

a Model adjusted for mean daily alcohol consumption, smoking status, and the psychosocial exposure measures demand and support.

b Park workers: altogether 1337 were entered into the model, of these 130 had reported nausea. 
agents in question, bioaerosols, were assumed to be present among at least $70 \%$ (of those exposed) of the 1337 respondents who became a part of the study.

Both the development and use of the job-exposure matrix seemed to have been successful. Using a job-exposure matrix, however, requires the assumption of homogeneous exposure within each work process (31), and in our study, which included a large group of waste collectors in a few work processes, the accuracy of that assumption was somewhat uncertain (table 3 ).

Misclassification occurs in the conversion from information about self-reported work conditions collected through a questionnaire, to work processes, to estimated or measured levels of exposure, to calculated weekly "inhaled" exposure, and, finally, to the exposure groups. The calculation of the "inhaled" exposure further requires an assumption of an identical lung ventilation rate for all persons entering a work process. The magnitude and direction of the differential misclassification (no exposure measurements conducted among the comparison group) could not be measured, as no standard exists concerning waste collectors' bioaerosol exposure.

The grouping of continuous exposure measures into exposure groups does not reduce misclassification. As the same amount of misclassification was assumed for each group, the exposure-response relationship should not have been disturbed by this type of misclassification. Moreover, the interpretation of the results are more straightforward when the exposures are grouped (32). It has been recommended that the grouping of exposure be restricted to health outcomes having a short induction time, for example, nausea and diarrhea (33).

The goal was to ensure a relatively high exposure contrast when the continuously measured exposure was grouped. For some of the exposure parameters, an exposure contrast of a factor 10 between 2 groups did not lead to a real contrast. Thus the described exposure-response relationship may have been due to chance. Moreover, the risk estimates may vary according to the grouping of exposure $(34-35)$.

The validity of the job-exposure matrix in general could not be evaluated. The classification of the exposure measures has however, been validated for a single work process by comparing an extrapolated exposure indicator with an exposure measurement (28).

Despite the general limitations in the use of the jobexposure matrix due to misclassification of exposure, this method proved useful in this study. It gave more precise estimates of the risk of reporting nausea or diarrhea than an evaluation in which only single exposure variables were corrected for in the analysis (14).

This study indicated a linear exposure-response relationship between exposure to fungal spores and endotoxins and gastrointestinal problems. No linear association was found for the total count of fungal spores and microorganisms. It is unknown whether the fungal spores

Table 7. Multivariate analysis of the exposure-response relationship between the weekly level of bioaerosol exposure and diarrhea for the waste collectors. $\left(\mathrm{PP}_{1}=\right.$ percentage with diarrhea according to the total group size, $\mathrm{PP}_{2}=$ percentage with diarrhea according to the total population, $\mathrm{PPR}=$ prevalence proportion ratio, $95 \% \mathrm{Cl}=95 \%$ confidence interval, $p_{\text {trend }}=$ test for trend, $p_{\text {trend } 2}=$ test for trend, without the comparison group, $\mathrm{p}_{\mathrm{HL}}=$ Hosmer-Lemeshow's goodness-of-fit test, Area $\mathrm{HOC}_{\mathrm{C}}=$ area under the ROC curve, cfu = colony-forming units)

\begin{tabular}{|c|c|c|c|c|c|c|c|c|c|c|}
\hline Parameter & $\begin{array}{l}\text { Level of } \\
\text { exposure }\end{array}$ & $\begin{array}{l}\text { Number of } \\
\text { exposed } \\
\text { persons }\end{array}$ & $P P_{1}$ & $\mathrm{PP}_{2}$ & PPR & $95 \% \mathrm{Cl}$ & $\mathrm{p}_{\text {trend }}$ & $p_{\text {trend2 }}$ & $\mathrm{p}_{\mathrm{HL}}$ & Area $_{R 0 G}$ \\
\hline \multicolumn{11}{|l|}{ Fungi (cfu) ${ }^{a}$} \\
\hline $\begin{array}{l}\text { High exposure group } \\
\text { Medium exposure group } \\
\text { Low exposure group } \\
\text { Comparison group }\end{array}$ & $\begin{array}{c}>1 \cdot 10^{7} \\
>1 \cdot 10^{6}-1 \cdot 10^{7} \\
1 \cdot 10^{5}-1 \cdot 10^{6} \\
<1 \cdot 10^{5}\end{array}$ & $\begin{array}{r}10 \\
711 \\
229 \\
387\end{array}$ & $\begin{array}{r}40 \\
20 \\
18 \\
6\end{array}$ & $\begin{array}{r}2 \\
68 \\
20 \\
10\end{array}$ & $\begin{array}{r}5.60 \\
3.45 \\
3.02 \\
1\end{array}$ & $\begin{array}{c}2.39-13.08 \\
2.24-5.31 \\
1.86-4.92 \\
-\end{array}$ & 0.001 & 0.29 & 0.50 & 0.70 \\
\hline \multicolumn{11}{|c|}{ Total count of fungal spores (cells) ${ }^{a}$} \\
\hline $\begin{array}{l}\text { High exposure group } \\
\text { Medium exposure group } \\
\text { Low exposure group } \\
\text { Comparison group b }\end{array}$ & $\begin{array}{c}>2 \cdot 10^{7} \\
>2 \cdot 10^{6}-2 \cdot 10^{7} \\
2 \cdot 10^{5}-2 \cdot 10^{6} \\
<2 \cdot 10^{5}\end{array}$ & $\begin{array}{r}68 \\
813 \\
69 \\
387\end{array}$ & $\begin{array}{r}18 \\
20 \\
22 \\
6\end{array}$ & $\begin{array}{r}6 \\
77 \\
7 \\
10\end{array}$ & $\begin{array}{r}2.91 \\
3.40 \\
3.53 \\
1\end{array}$ & $\begin{array}{l}1.52-5.55 \\
2.22-5.22 \\
1.94-6.41\end{array}$ & 0.94 & 0.62 & 0.14 & 0.70 \\
\hline \multicolumn{11}{|c|}{ Total count of microorganisms (cells) ${ }^{\mathrm{a}}$} \\
\hline $\begin{array}{l}\text { High exposure group } \\
\text { Medium exposure group } \\
\text { Low exposure group } \\
\text { Comparison group b }\end{array}$ & $\begin{array}{c}>6 \cdot 10^{7} \\
>6 \cdot 10^{6}-6 \cdot 10^{7} \\
6 \cdot 10^{5}-6 \cdot 10^{6} \\
<6 \cdot 10^{5}\end{array}$ & $\begin{array}{r}18 \\
847 \\
85 \\
387\end{array}$ & $\begin{array}{r}17 \\
20 \\
20 \\
6\end{array}$ & $\begin{array}{r}1 \\
80 \\
8 \\
11\end{array}$ & $\begin{array}{r}2.55 \\
3.39 \\
3.42 \\
1\end{array}$ & $\begin{array}{c}0.86-7.58 \\
2.21-5.19 \\
1.91-6.11 \\
-\end{array}$ & 0.95 & 0.95 & 0.10 & 0.70 \\
\hline \multicolumn{11}{|l|}{ Endotoxins $(E U)^{\mathrm{a}}$} \\
\hline $\begin{array}{l}\text { High exposure group } \\
\text { Medium exposure group } \\
\text { Low exposure group } \\
\text { Comparison group }\end{array}$ & $\begin{array}{c}>5 \cdot 10^{2} \\
>1 \cdot 10^{2}-5 \cdot 10^{2} \\
0.001 \cdot 10^{2}-1.10^{2} \\
<0.001 \cdot 10^{2}\end{array}$ & $\begin{array}{r}90 \\
730 \\
130 \\
387\end{array}$ & $\begin{array}{r}28 \\
19 \\
18 \\
6\end{array}$ & $\begin{array}{l}12 \\
66 \\
11 \\
11\end{array}$ & $\begin{array}{r}4.59 \\
3.25 \\
3.15 \\
1\end{array}$ & $\begin{array}{c}2.74-7.71 \\
2.11-5.00 \\
1.84-5.41 \\
-\end{array}$ & $<0.001$ & 0.15 & 0.32 & 0.71 \\
\hline
\end{tabular}

a Model adjusted for the mean daily alcohol consumption, smoking status, and the psychosocial exposure measures demand and support.

b Park workers; altogether 1337 were entered into the model, of these 210 had reported diarrhea. 
cause the health problems or whether the fungal spores measured indicate the presence of other microorganisms $(36-37)$. High microbial activity may also cause emissions of volatile organic compounds from waste (38), and exposure to such compounds has been reported as a cause of gastrointestinal problems (39).

The lack of a linear exposure-response association between gastrointestinal problems and the total count of microorganisms and fungal spores as a measure of exposure to these bioaerosols may be due to too high a detection limit of the analytical method. Therefore some uncertainty may be reflected in the low concentrations of microorganisms counted. It is not plausible to assume that the lack of linear association was due to an improved tolerance in the highly exposed groups (40). If this were the case, an equal pattern could have been expected for all 4 exposure parameters.

To our knowledge this is the first job-exposure matrix developed for bioaerosol exposure in the waste collection industry. With this approach we were able to show a linear exposure-response relationship between nausea and endotoxin exposure and also between diarrhea and exposure to both endotoxins and viable fungi.

\section{Acknowledgments}

This study was part of the 1993-1998 research program Waste Collection and Recycling which has been jointly supported by the Danish Ministry of the Environment and the Ministry of Labour.

\section{References}

1. Poulsen OM, Breum NO, Ebbehøj N, Hansen AAM, Ivens UI, van Lelieveld D, et al. Collection of domestic waste. review of occupational health and their possible causes. Sci Total Environ 1995;170:1-19.

2. Malmros P, Sigsgaard T, Bach B. Occupational health problems due to garbage sorting. Waste Manage Res 1992;10:227-34

3. Breum NO, Nielsen BH, Nielsen EM, Midtgaard U, Poulsen OM. Dustiness of compostable waste: a methodological approach to quantify the potential of waste to generate airborne micro-organisms and endotoxin. Waste Manage Res 1997:15:169-87.

4. Dutkiewicz J, Jablonski L, Olenchock S. Occupational biohazards: a review. Am J Ind Med 1988;14:605-23.

5. Burge HA. Classification of the fungi. Clin Rev Allergy 1992;10:153-63.

6. Lacey J, Dutkiewicz J. Bioaerosols and occupational lung diseases. J Aerosol Sci 1994;25:1371-404.

7. Dutkiewicz J. Bacterial and fungi in organic dust as potential health hazard. Ann Agric Environ Med 1997;4:11-6.

8. Lundholm M, Rylander R. Work related symptoms among sewage workers. Br J Ind Med 1983;40:325-9.

9. Zuskin E, Mustajbegovic J, Schacter EN. Respiratory function in sewage workers. Am J Ind Med 1993;23:751-61.

10. Lundholm $M$, Rylander $R$. Occupational symptoms among compost workers. J Occup Med 1980;22:256-7.

11. Rylander $R$. The role of endotoxin for reactions after exposure to cotton dust. Am J Ind Med 1987;12:687—97.

12. Andersen T, Petersen C, Bjørn K, Wibroe L, Ebbehøj N. Arbejdsmiljøproblemer ved indsamling af organisk husholdningsaffald [Problems in the work environment when collecting organic waste]. Copenhagen: The Danish EPA, 1993.

13. Netterstrøm B. Vurdering af helbredsmassige effekter hos renovationsarbejdere ved indsamling af grønt affald. AFAV [Health effects among waste collectors when collecting organic waste]. Copenhagen: The Danish EPA, 1990.

14. Ivens UI, Ebbehøj N, Poulsen OM, Skov T. Relation between season, equipment, and job function and gastrointestinal problems among waste collectors. Occup Environ Med 1997;54:861-7.

15. Ivens UI, Hansen J, Breum NO, Ebbehøj N, Poulsen OM, Skov $\mathrm{T}$, et al. Diarrhea among waste collectors associated with bioaerosol exposure. Ann Agric Environ Med 1997;4:63-8.

16. Kauppinen TP. Assessment of exposure in occupational epidemiology. Scand J Work Environ Health 1994;20 special issue: $19-29$.

17. Coughlin SS, Chiazze Jr L. Job-exposure matrices in epidemiologic research and medical surveillance. Occup Med 1990;5:633-46.

18. Ivens UI, Hansen J, Skov T, Poulsen OM, Ebbehøj N. Sikkerhed og sundhed ved affald og genanvendelse. Spørgeskemaunders $\varnothing$ gelsen blandt skraldemænd - Baselineunders $\varnothing$ gelsen [Occupational safety and health in waste collection and recycling: the questionnaire study among waste collectors: the baseline study]. Copenhagen: National Institute of Occupational Health, 1996. English summary.

19. Hansen J, Ivens UI, Breum NO, Nielsen M, Würtz H, Skov T, et al. Respiratory symptoms among Danish waste collectors. Ann Agric Environ Med 1997;4:69 - 74.

20. Raaskov-Nielsen O, Nielsen ML, Gehl J. Traffic-related air pollution: exposure and health effects in Copenhagen street cleaners and cemetery workers. Arch Environ Health 1995;50:207-13.

21. Wiktorin C, Karlquist L, Winkel J, Stockholm MUSIC I study group. Validity of self-reported exposures to work postures and manual materials handling. Scand $\mathbf{J}$ Work Environ Health 1993;19:208-14.

22. North F, Syme SL, Feeney A, Head J, Shipley MJ, Marmot MG. Explaining socioeconomic differences in sickness absence: the Whitehall II study. BMJ 1993;306:361-6.

23. Kristensen TS. The demand-control-support model: methodological challenges for future research. Stress Med 1995;11:17-26.

24. Karasek R. Job demands, job decision latitude, and mental strain: implications for job redesign. Adm Sci Q 1979;24:285-308.

25. Bouyer J, Hémon D. Retrospective evaluation of occupational exposures in population-based case-control studies: general overview with special attention to job exposure matrices. Int $J$ Epidemiol 1993;22:s57-s64.

26. Nielsen EM, Breum NO, Nielsen BH, Midtgaard U, Poulsen OM. Bioaerosol exposure in waste collection: a comparative study on the significance of collection equipment, type of waste and seasonal variation. Ann Occup Hyg 1997;41:325- 
44.

27. van Ooijen M, Ivens UI, Johansen C, Skov T. Comparison of a self-administrated questionnaire and a telephone interview of 146 Danish waste collectors. Am J Ind Med 1997;31:6538.

28. Breum NO, Nielsen M, Würtz H, Ivens UI, Hansen J, Schibye $\mathrm{B}$, et al. A job exposure matrix related to bioaerosol exposure during collection of household waste. Ann Agric Environ Med 1997:4:53-61.

29. Skov T, Deddens J, Petersen M, Endahl L. Prevalence proportion ratios: estimation and hypothesis testing. Int J Epidemiol 1998;27:91-5.

30. Kauppinen TP, Mutanen PO, Seitsamo JT. Magnitude of misclassification bias when using a job-exposure matrix. Scand J Work Environ Health 1992;18:105-12.

31. Smith TJ. Exposure assessment for occupational epidemiology. Am J Ind Med 1987;12:249—68.

32. Armstrong BK, White E, Saracci R. Principles of exposure measurement in epidemiology. New York (NY): Oxford University Press, 1994.

33. Checkoway H, Seixas NS, Demers PA. The influence of occupational exposure assessment of epidemiological inferenc- es. Occup Hyg 1996;3:7-21.

34. Schulgen G, Laursen B, Olsen JH, Schumacher M. Outcome oriented cutpoint in analysis of quantitative exposures. Am $\mathrm{J}$ Epidemiol 1994;140:172-84.

35. Hornung R. Statistical evaluation of exposure assessment strategies. Appl Occup Environ Hyg 1991;6:516-20.

36. Douwes J, Heederik D. Epidemiologic investigations of endotoxins. Int J Occup Environ Health 1997;3:s26-s31.

37. Malmberg P. Mikroorganismer [Microorganisms; summary in English]. Stockholm: Arbetarskyddsverket, 1991:1-29. Arbete och Hälsa 44.

38. Wilkins KC. Volatile organic compounds from household waste. Chemosphere 1994;29:47-53.

39. Wilkins KC. Gaseous organic emissions from various types of household waste. Ann Agric Environ Med 1997;4:87-9.

40. Kennedy SM, Christiani DC, Eisen EA, Wegman DH, Greaves IA, Olenchock SA, et al. Cotton dust and endotoxin exposure-response relationships in cotton textile workers. Am Rev Respir Dis 1987;135:194-200.

Received for publication: 28 September 1998 